\title{
First records of the order Polycladida (Platyhelminthes, Rhabditophora) from reef ecosystems of Alagoas State, north-eastern Brazil, with the description of Thysanozoon alagoensis sp. nov.
}

\author{
JULIANA BAHIA ${ }^{1,2}$, VINICIUS PADULA ${ }^{1,2}$, MÔNICA DORIGO CORREIA ${ }^{3}$ AND HILDA H. SOVIERZOSKI ${ }^{3}$ \\ ${ }^{1}$ SNSB-Zoologische Staatssammlung München, Münchhausenstrasse 21, 81247, München, Germany, ${ }^{2}$ Department Biology II \\ and GeoBio-Center, Ludwig-Maximilians Universität München, Germany, ${ }^{3}$ Universidade Federal de Alagoas, Setor de Comunidades \\ Bentônicas (LABMAR/ICBS), Rua Aristeu de Andrade, 452- 20 andar, Farol, CEP 57021090, Maceió, AL, Brazil
}

\begin{abstract}
The $230 \mathrm{~km}$ long coast of Alagoas State, in north-eastern Brazil, has diverse reef ecosystems, made from corals and of sandstone, that harbour a wide range of marine invertebrate fauna. Little is known about turbellarians of the order Polycladida in most parts of the Brazilian coast, with no record from Alagoas up to date. To fill this gap expeditions were conducted on the reefs from the central coast of Alagoas, where 11 Polycladida species were found: Pericelis cata, Enchiridium evelinae, Pseudoceros bicolor and a possible new colour variation of this species, Pseudoceros rawlinsonae, Pseudobiceros pardalis, Thysanozoon brocchii, Thysanozoon alagoensis sp. nov., Armatoplana leptalea, Adenoplana evelinae, Latocestus brasiliensis, Phaenocelis medvedica. The species are described in detail through photos of live specimens and histological sections. The present work adds six species to the north-eastern Brazilian coast, one of them a new species, and all 11 species are for the first time reported from Alagoas State. Also, it is the first time that Phaenocelis medvedica, Adenoplana evelinae, Latocestus brasiliensis and Armatoplana leptalea are illustrated by full colour photos of live specimens and histological sections.
\end{abstract}

Keywords: marine flatworms, Brazilian biodiversity, taxonomy

Submitted 2 June 2014; accepted 29 May 2015; first published online 26 June 2015

\section{INTRDDUCTIDN}

Animals belonging to the order Polycladida are free-living platyhelminthes, with most species known from tropical seas. About 900 species have been described around the world (Newman \& Cannon, 2003). Among them, about 125 were reported from the Tropical Western Atlantic, 70 occur in Brazil, 46 being endemic (Quiroga et al., 2004a; Bahia et al., 2014). From the Brazilian coast, the existing knowledge is mostly the result of works conducted between 1950 and 1970, based on specimens collected at São Paulo region (Marcus, 1947, 1948, 1949, 1950, 1952). Recent contributions, including new local and country records were made by Bahia \& Padula (2009), Bahia et al. (2012, 2014) and Queiroz et al. (2013).

On the north-eastern Brazilian coast, such as in the state of Alagoas, reef ecosystems are abundant and have a rich biological diversity (Correia \& Sovierzoski, 2009). These reefs include a benthic fauna, which provide various natural substrates for the Polycladida, composed mainly of sponges (Cedro et al., 2007, 2011, 2013; Bispo et al., 2014), corals (Correia, 2011) and bryozoans (Vieira et al., 2007, 2008, 2010). A variety of algae also provides habitats for numerous

Corresponding author:

J. Bahia

Email: ju.bahia@yahoo.com associated organisms (Santos \& Correia, 1994, 1995, 2001), which are important environments for flatworms and other small invertebrates such as opisthobranch molluscs (Padula et al., 2012) and echinoderm brittle stars (Lima et al., 2011, 2013). However, there is a significant lack of information, particularly about marine platyhelminthes in this region, with no record of the order Polycladida from Alagoas reef ecosystems. Herein we aim to present the first records of Polycladida from Alagoas coast, including the description of a new species.

\section{MATERIALS AND METHODS}

Alagoas coast is approximately $230 \mathrm{~km}$ long, and it is limited by the Persinunga River on the north and by the São Francisco River on the south $\left(8^{\circ} 54^{\prime} \mathrm{S}-35^{\circ} 9^{\prime} \mathrm{W}\right.$ and $\left.10^{\circ} 30^{\prime} \mathrm{S}-36^{\circ} 23^{\prime} \mathrm{W}\right)$, The main ecosystems that can be found are coral and sandstone reefs, lagoons, rivers and mangroves. The coral reefs were formed on calcareous sedimentary rock, composed of an aggregation of dead organisms, including skeletons of corals and hydrocorals combined with crusts of calcareous algae and other invertebrates (Correia \& Sovierzoski, 2009). Many of these fringing reefs are located near the beach line, where the top of the reef platform is exposed during low tides. The sandstone reefs were formed by old sandbanks solidified through sedimentation, starting from chemical 
reactions with calcium carbonate from the Quaternary Period, and are generally arranged in rows parallel to the coastline and near the outlets of rivers and estuaries (Correia \& Sovierzoski, 2009; Correia, 2011).

All specimens were manually collected under rocks at the intertidal zone or in the sublittoral by snorkelling or scuba diving along the edge of the reef platforms during low tide. Collections were conducted in January 2008 and January 2012, and were carried out in reef ecosystems along the central coast of Alagoas State, Brazil (Figure 1). Seven reef ecosystems were sampled: coral reefs of Ponta Verde $\left(9^{\circ} 39^{\prime} 57^{\prime \prime} \mathrm{S}-\right.$ $\left.35^{\circ} 41^{\prime} 32^{\prime \prime} \mathrm{W}\right)$, Jatiúca $\left(9^{\circ} 39^{\prime} 12^{\prime \prime} \mathrm{S}-35^{\circ} 41^{\prime} 46^{\prime \prime} \mathrm{W}\right)$, Piscina dos Amores $\left(9^{\circ} 40^{\prime} 39^{\prime \prime} \mathrm{S}-35^{\circ} 42^{\prime} 10^{\prime \prime} \mathrm{W}\right)$, Pajuçara $\left(9^{\circ} 41^{\prime} 06^{\prime \prime} \mathrm{S}-\right.$ $\left.35^{\circ} 43^{\prime} 22^{\prime \prime} \mathrm{W}\right)$ and Riacho Doce $\left(9^{\circ} 34^{\prime} 55^{\prime \prime} \mathrm{S}-35^{\circ} 39^{\prime} 25^{\prime \prime}\right)$, and sandstone reefs of Francês $\left(9^{\circ} 46^{\prime} 03^{\prime \prime} \mathrm{S}-35^{\circ} 50^{\prime} 13^{\prime \prime} \mathrm{W}\right)$ and Saco da Pedra ( $9^{\circ} 44^{\prime} 26^{\prime \prime} \mathrm{S}-35^{\circ} 48^{\prime} 59^{\prime \prime} \mathrm{W}$ ) (Figure 1 ).

In the laboratory, specimens were photographed alive with a digital camera. Afterwards, they were fixed in $10 \%$ frozen formalin, following a modified methodology (Newman \& Cannon, 2003), and transferred to $70 \%$ ethanol for histological preparation. Specimens were measured after fixation (length $\mathrm{mm} \times$ width $\mathrm{mm}$ ). The identification was based on morphological characteristics, colouration pattern, ocelli position and slides of the reproductive structures stained by haematoxylin-eosin method (Bolaños et al., 2007). Specimens were compared with original descriptions and previous publications (Marcus, 1949, 1950, 1952; Marcus \& Marcus, 1968; Bolaños et al., 2007). Collected material was deposited on the Platyhelminthes collection in the Museu Nacional/ Universidade Federal do Rio de Janeiro, Brazil (MNRJ-PLAT).

\section{RESULTS}

There were 35 specimens found belonging to 11 species of the order Polycladida. Pericelis cata, Enchiridium evelinae, Pseudoceros bicolor, Pseudoceros rawlinsonae, Pseudobiceros pardalis, Thysanozoon brocchii, Thysanozoon alagoensis sp. nov., Armatoplana leptalea, Adenoplana evelinae, Latocestus brasiliensis and Phaenocelis medvedica. The species Enchiridium evelinae was the most common, with 15 specimens collected, and found in all sampled reefs. Greater species richness was observed at Saco da Pedra reef. The lowest richness was found at Piscina dos Amores coral reef. All occurrences reported here are the first records of Polycladida from Alagoas ecosystems (Table 1). As some of the species found in this study were treated on previous papers by the authors, just the material examined, with measurements, distribution and remarks are included.

\section{SYSTEMATICS}

Order POLYCLADIDA Lang, 1884

Suborder COTYLEA Lang, 1884

Family PERICELIDAE Laidlaw, 1902

Genus Pericelis Laidlaw, 1902

Pericelis cata Marcus \& Marcus, 1968

(Figure 2B)

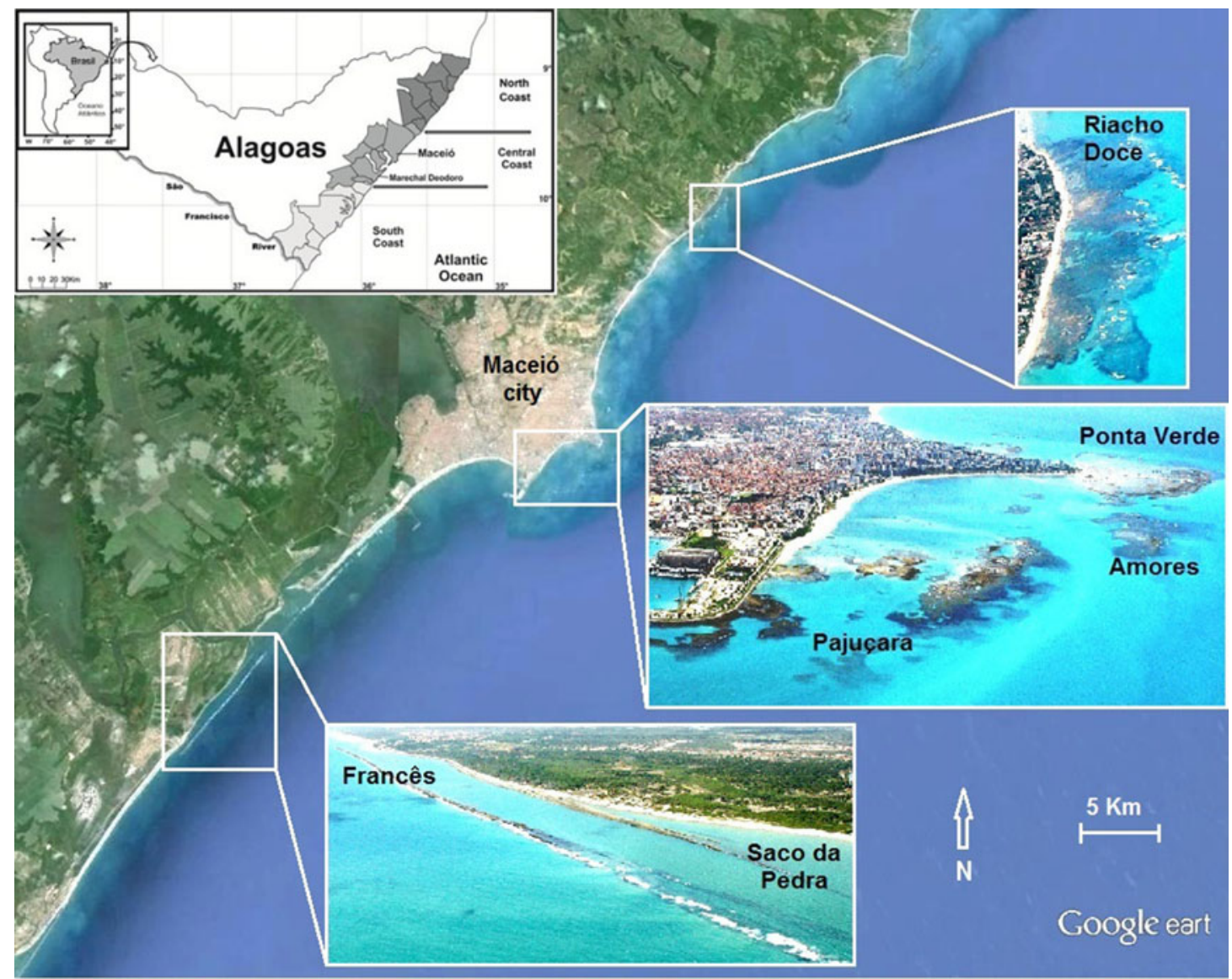

Fig. 1. Map of reef environments studied at Alagoas State, north-eastern Brazil. 
Table 1. Species and number of specimens found at each reef ecosystem on the Alagoas coast.

\begin{tabular}{|c|c|c|c|c|c|c|c|}
\hline SPECIES & Ponta Verde & Francês & Riacho Doce & $\begin{array}{l}\text { Saco } \\
\text { da Pedra }\end{array}$ & $\begin{array}{l}\text { Piscina } \\
\text { dos Amores }\end{array}$ & Pajuçara & $\begin{array}{l}\text { Number of } \\
\text { specimens }\end{array}$ \\
\hline Enchiridium evelinae & 1 & 2 & 2 & 6 & 2 & 2 & 15 \\
\hline Pseudoceros bicolor & & & & 2 & & & 2 \\
\hline Pseudoceros rawlinsonae & & & & 1 & & & 1 \\
\hline Pseudoceros cf. bicolor & & 2 & & & & & 2 \\
\hline Pseudobiceros pardalis & & & & 1 & & & 1 \\
\hline Thysanozoon brocchii & & 1 & & 2 & & & 3 \\
\hline Thysanozoon alagoensis sp. nov. & & & & 1 & & & 1 \\
\hline Pericelis cata & & & & 1 & & & 1 \\
\hline Phaenocelis medvedica & 1 & & & & & & 1 \\
\hline Armatoplana leptalea & & & 3 & 1 & & & 4 \\
\hline Adenoplana evelinae & & & & 1 & & 1 & 2 \\
\hline Latocestus brasiliensis & 1 & & & & & 1 & 2 \\
\hline No. of species & 3 & 3 & 2 & 9 & 1 & 3 & Total:11/35 \\
\hline
\end{tabular}

\section{EXAMINED MATERIAL}

One mature specimen $(18 \times 16 \mathrm{~mm})$ as sagittal sections of reproductive structures (MNRJ-PLAT 96, 13 slides). Collected 26 January 2012 at Saco da Pedra sandstone reef, Marechal Deodoro, Alagoas, Brazil.

\section{GEOGRAPHIC DISTRIBUTION}

This species was recorded from Curaçao (type locality; Marcus \& Marcus, 1968), Colombian Caribbean (Quiroga et al., 2004b), Cabo Frio, south-eastern Brazil (Bahia \& Padula, 2009) and Salvador, north-eastern Brazil (Queiroz et al., 2013). This is the first record of this species from Alagoas State.

\section{REMARKS}

The specimen herein studied was smaller than those found at Cabo Frio, south-eastern Brazil (Bahia \& Padula, 2009) and those from Bahia State, north-eastern Brazil (Queiroz et al., 2013). During the collections two specimens of $P$. cata were placed in the same container as some specimens of the opisthobranch mollusc Micromelo undatus. When freed to be photographed the Pericelis were much damaged and one was not useful for study. This could have happened because

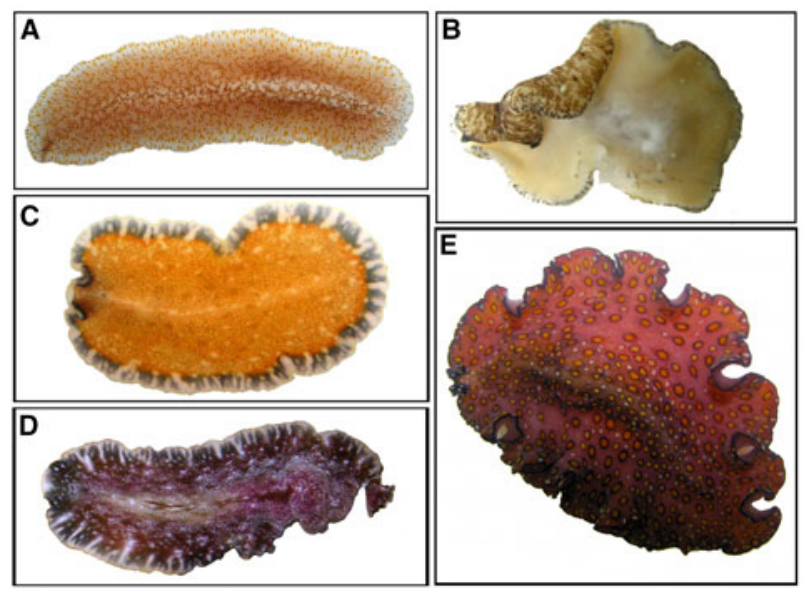

Fig. 2. (A) Enchiridium evelinae (MNRJ-PLAT 80); (B) Pericelis cata (MNRJ-PLAT 96); (C) Pseudoceros bicolor (MNRJ-PLAT 85); (D) Pseudoceros rawlinsonae (MNRJ-PLAT 87); (E) Pseudobiceros pardalis (MNRJ-PLAT 92). of some fighting with the molluscs or some toxic chemical compound they might present.

\section{Family PROSTHIOSTOMIDAE Lang, 1884 \\ Genus Enchiridium Bock, 1913 \\ Enchiridium evelinae Marcus, 1949}

(Figure 2A)

\section{EXAMINED MATERIAL AND LOCALITY}

One mature specimen (MNRJ-PLAT 77, $32 \times 9 \mathrm{~mm}$ ) collected 6 January 2008 at Brazil, Alagoas, Maceió, Ponta Verde coral reef. One mature specimen (MNRJ-PLAT 78, $29 \times 8 \mathrm{~mm}$ ) collected 7 January 2008 at Pajuçara coral reef, Maceió, Alagoas, Brazil. Two specimens (MNRJ-PLAT 79, $26 \times 6 \mathrm{~mm}$ and $30 \times 8 \mathrm{~mm}$ ) collected 9 January 2008 at Francês sandstone reef, Maceió, Alagoas, Brazil. Two specimens (MNRJ-PLAT 80, $21 \times 7 \mathrm{~mm}$ and $32 \times 10 \mathrm{~mm}$ ). One as sagittal sections of reproductive structures (21 slides). Collected 10 January 2008 at Riacho Doce coral reef, Maceió, Alagoas, Brazil. Five specimens (MNRJ-PLAT 81, $6 \times 3 \mathrm{~mm}, 12 \times 5 \mathrm{~mm}, 16 \times 6 \mathrm{~mm}, 21 \times 7 \mathrm{~mm}$ and $23 \times$ $8 \mathrm{~mm}$ ) collected 11 January 2008 at Saco da Pedra sandstone reef, Marechal Deodoro, Alagoas, Brazil. Two specimens (MNRJ-PLAT $82,21 \times 7 \mathrm{~mm}$ and $22 \times 7 \mathrm{~mm}$ ) collected 13 January 2008 at Piscina dos Amores coral reef, Maceió, Alagoas, Brazil. One specimen (MNRJ-PLAT 83, $18 \times$ $7 \mathrm{~mm}$ ) collected 7 February 2008 at Pajuçara coral reef, Maceió, Alagoas, Brazil. One specimen (MNRJ-PLAT 84, $26 \times 11 \mathrm{~mm}$ ) collected 27 January 2012 at Saco da Pedra sandstone reef, Maceió, Alagoas, Brazil. All specimens preserved in $70 \%$ ethanol.

\section{GEOGRAPHIC DISTRIBUTION}

Originally described from São Paulo State, south-eastern Brazil (Marcus, 1949) reported to Rio Grande do Norte State (Bahia et al., 2012), Rio de Janeiro State (Bahia et al., 2014) and now Alagoas State, north-eastern Brazil. It is also known from Curaçao (Marcus \& Marcus, 1968). This species is considered by Rawlinson (2008) as representative of seagrass habitat. We found our specimens both in sandstone and coral reefs and E. evelinae was the most common species in our samplings. This is the first record of this species from Alagoas State. 


\section{REMARKS}

This species was observed copulating (video in Supplementary material). It presented reciprocal insemination and a somewhat violent penis-fencing behaviour. Unfortunately the following eggmass laying could not be observed. Also one specimen of Enchiridium evelinae ate a specimen of Adenoplana evelinae during a fortnight in the same Petri dish. We noticed differences in colouration between the specimens found in Alagoas and those from Rio de Janeiro, the latter sometimes has a different distribution of the dorsal brown spots, with them more densely disposed in the median line (personal observation).

\section{Family PSEUDOCEROTIDAE Lang, 1884 \\ Genus Pseudoceros Lang, 1884 \\ Pseudoceros bicolor Verrill, 1901 \\ (Figures 2C \& 3 )}

\section{EXAMINED MATERIAL}

One mature specimen $(12 \times 8 \mathrm{~mm})$ as sagittal sections of reproductive structures (MNRJ-PLAT 85,9 slides). One mature specimen (MNRJ-PLAT $86,10 \times 8 \mathrm{~mm}$ ) collected 26 January 2012. Both collected at Saco da Pedra sandstone reef, Marechal Deodoro, Alagoas, Brazil and preserved in $70 \%$ ethanol. One mature specimen $(11 \times 10 \mathrm{~mm})$ as sagittal section of reproductive structures (MNRJ-PLAT 90, 16 slides). One mature specimen $(15 \times 10 \mathrm{~mm})$ as sagittal section of reproductive structures (MNRJ-PLAT 91, 15 slides). Both collected 25 January 2012 at Francês sandstone reef, Marechal Deodoro, Alagoas, Brazil.

\section{GEOGRAPHIC DISTRIBUTION}

Described from Bermudas (type locality; Verrill, 1901), reported from Curacao (Marcus \& Marcus, 1968), Caribbean coast of Colombia (Quiroga et al., 2004b), Florida, Virgin Islands, Jamaica, Belize, Honduras, Caribbean coast of Panama (Rawlinson, 2008) and south-eastern Brazil (Bahia \& Padula, 2009). This is the first record of this species from north-eastern Brazil.

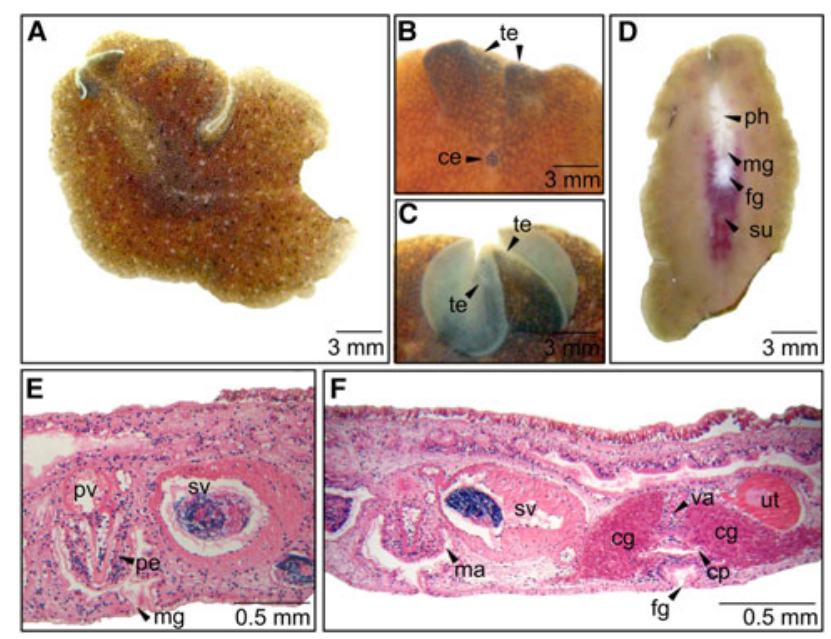

Fig. 3. Pseudoceros cf. bicolor (A) in vivo; (B) and (C) detail of the anterior region; (D) ventral view; (E) sagittal section of male reproductive structures; (F) sagittal section of male and female reproductive structures. ce, cerebral eyespots; cg, cement glands; cp, cement pouch; fg, female gonopore; ma, male atrium; mg male gonopore; pe, penis; ph, pharynx; pv, prostatic vesicle; su, sucker; sv, seminal vesicle; te, tentacular eyespots; ut, uteri; va, vagina.

\section{REMARKS}

The specimens MNRJ-PLAT 85 and 86 are in accordance with the description and posterior amendment. Specimens MNRJ-PLAT 90 and MNRJ-PLAT 91 (at Table 1 counted separately as Pseudoceros cf. bicolor) were somewhat different from the former specimens. Their background colour was yellowish orange with scattered white and dark spots (Figure $3 \mathrm{~A}$ ); whitish translucent marginal band with a thin light yellow outermost line, only seen in live specimens. Seminal vesicle muscularized and elongated. Prostatic vesicle rounded and small, located above the penial papillae (Figure $3 \mathrm{E}$ ). They resemble Pseudoceros bicolor in its background coloration pattern, but it lacks the white marginal band with black languettes characteristic of this species. Also the colour has hints of orange that are absent in specimens from the same locality and from other regions of the Brazilian coast (Bahia \& Padula, 2009), and the seminal vesicle of these specimens is more elongated than rounded as usually found in P. bicolor. The material differs from the recently described $P$. juani in body proportion length $\times$ width, this species has a more elongated body (Bahia et al., 2014) than the Pseudoceros specimens found in Alagoas. Also, the seminal vesicle of $P$. juani is proportionally much larger than in $P$. bicolor and in the two specimens studied. However both $P$. juani and the two studied specimens have both scattered white and dark spots and there is a hint of orange in Alagoas' specimens, which is the background colour of $P$. juani, therefore we cannot rule out that those specimens can be some morphotype between $P$. bicolor and $P$. juani, despite the latter having no record in Alagoas so far. These two specimens are here, for now, identified as $P$. bicolor; this should be confirmed through a future molecular analysis.

Pseudoceros rawlinsonae Bolaños, Quiroga \& Litvaitsi, 2007 (Figure 2D)

\section{EXAMINED MATERIAL}

One mature specimen $(10 \times 6 \mathrm{~mm})$ as sagittal sections of reproductive structures (MNRJ-PLAT 87,18 slides). Collected 11 January 2008 at Saco da Pedra sandstone reef, Marechal Deodoro, Alagoas, Brazil.

\section{GEOGRAPHIC DISTRIBUTION}

Originally described from the American Virgin Islands and Bonaire (Bolaños et al., 2007). After the revision of Pseudoceros bicolor complex, $P$. rawlinsonae was also reported from Florida, Honduras, Jamaica, Bahamas, Curaçao (Litvaitis et al., 2010) and south-eastern Brazil (Bahia \& Padula, 2009, as P. bicolor; Bahia et al., 2014). This is the first record of this species from north-eastern Brazil.

Genus Pseudobiceros Faubel, 1984

Pseudobiceros pardalis (Verrill, 1900)

(Figure 2E)

\section{EXAMINED MATERIAL}

One specimen $(45 \times 37 \mathrm{~mm})$ as sagittal sections of reproductive structures (MNRJ-PLAT 92, 35 slides). Collected 27 January 2012 at Saco da Pedra sandstone reef, Marechal Deodoro, Alagoas, Brazil. 


\section{GEOGRAPHIC DISTRIBUTION}

Pseudobiceros pardalis was described from Bermudas (Verrill, 1900) and reported from Bahamas, south Florida and Panama (Bolaños et al., 2007). It was recently reported for the first time from Brazil, but south from Alagoas (Bahia et al., 2014). This is the first record of this species from north-eastern Brazil.

\section{REMARKS}

Our specimens have lighter colouration than the ones in the original description (Verrill, 1900) and re-description (Bolaños et al., 2007), but darker than reported from south-eastern Brazil (Bahia et al., 2014), probably due to differences in size and the nutritional conditions of the animals. The specimens found in the Caribbean (Bolaños et al., 2007) have a concentration of white dots near the margin that is not so clear in Brazilian specimens (Figure $2 \mathrm{E}$ ), both from Alagoas and from Rio de Janeiro (Bahia et al., 2014).

Genus Thysanozoon Grube, 1840

Thysanozoon brocchii (Risso, 1818)

(Figure 4)

\section{EXAMINED MATERIAL}

Two specimens $(22 \times 18 \mathrm{~mm}$ and $6 \times 4 \mathrm{~mm})$, the mature as sagittal sections of reproductive structures (MNRJ-PLAT 93, 29 slides). Collected 11 January 2008 at Saco da Pedra sandstone reef, Marechal Deodoro, Alagoas, Brazil. One specimen $(17 \times 20 \mathrm{~mm})($ MNRJ-PLAT 94) collected 25 January 2012 at Francês sandstone reef, Marechal Deodoro, Alagoas, Brazil.

\section{GEOGRAPHIC DISTRIBUTION}

Cosmopolitan species described from Naples, Italy (type locality; Risso, 1818) and other parts of the Mediterranean Sea, UK, south and west from Africa, Florida, Colombian Caribbean,
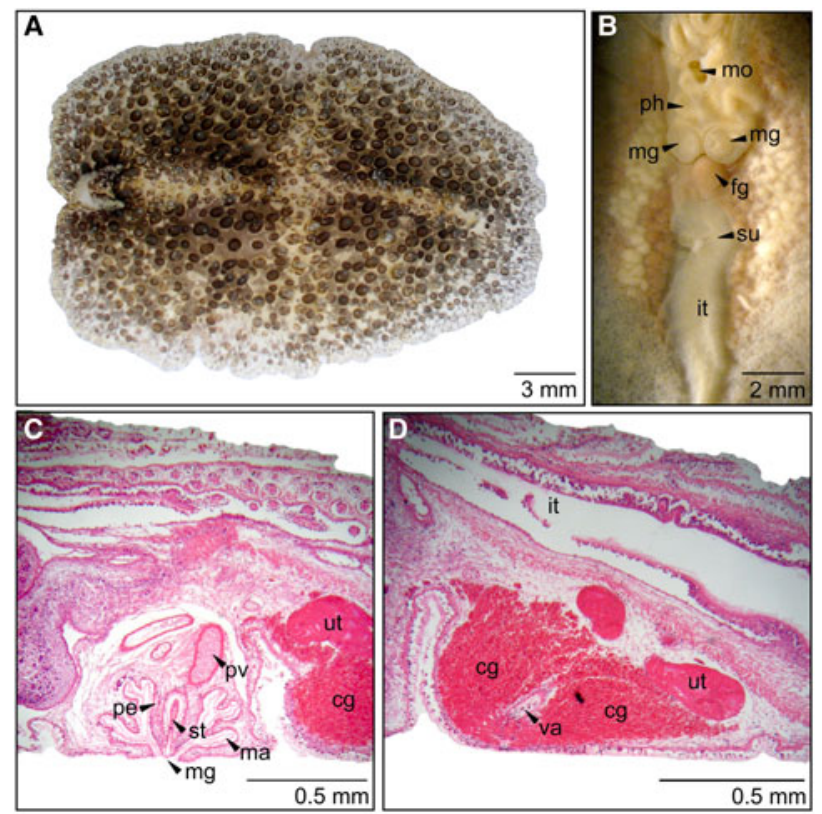

Fig. 4. Thysanozoon brocchii (A) in vivo; (B) detail of the ventral surface; (C) sagittal section of the male reproductive structures; (D) sagittal section of the female reproductive structures. cg, cement glands; fg, female gonopore; it, intestine; ma, male atrium; mg, male gonopore; mo, mouth; pe, penis; ph, pharynx; pv, prostatic vesicle; st, stylet; su, sucker; ut, uteri; va, vagina.
Brazil, Japan and New Zealand (Prudhoe, 1985; Quiroga et al., 2004b). It was also reported from Canary Islands (Vera et al., 2008), Argentina (Brusa et al., 2009), from northeastern (Bahia et al., 2012) and south-eastern Brazil (Bahia et al., 2014). This is the first record from Alagoas State.

\section{REMARKS}

The specimens found at Alagoas all have rounded papillae and brownish colouration (Figure 4A). This is not the case in some south-eastern Brazil and in the Mediterranean Sea specimens (Bahia et al., 2014). Specimens from those areas can have slender papillae and black to greyish colouration, and European specimens present a red marginal band (Bahia pers. obs.).

\section{Thysanozoon alagoensis sp. nov.} (Figures 5 \& 6)

\section{TYPE MATERIAL}

Holotype: one specimen $(19 \times 16 \mathrm{~mm})$, as sagittal sections of reproductive structures (MNRJ-PLAT 95, 26 slides). Collected 27 January 2012 at Saco da Pedra sandstone reef, Marechal Deodoro, Alagoas, Brazil, $4 \mathrm{~m}$ deep.

\section{GEOGRAPHIC DISTRIBUTION}

The species is only known from the type locality.

\section{ETYMOLOGY}

The specific name alagoensis makes reference to the geopolitical division of Brazil, Alagoas State, where the holotype specimen was found.

\section{DIAGNOSIS}

Greyish background colour with reddish brown papillae, reddish brown margin and dark almost black tentacles with a hint of yellowish pigmentation on the border. Unpigmented line present at the median line of the body. Tentacular eyespots arranged in a line at the border and a group of eyespots at each tentacular tip. Pharynx ruffled with seven simple folds. Seminal vesicle elongated and huge. Its extension reaches the front of the penial papillae and the seminal duct come in a curve to join the penis. Prostatic vesicle small and comma shaped. Male atrium simple. Greatly developed spermiducal vesicles.

\section{DESCRIPTION}

Colour: Greyish background colour with reddish brown papillae, reddish brown margin and dark almost black tentacles (Figure $5 \mathrm{~A}$ ). Some papillae are more lightly coloured, more like the background colour. Unpigmented line present at the median line of the body from the tentacles until the last $1 / 6$ of the body length (Figure $5 \mathrm{~A}$ ).

Form: Elongated with papillated dorsal surface (Figure ${ }_{5} \mathrm{~B}$ ) with slender whitish tipped papillae.

Tentacles: Dark almost black tentacles with a hint of yellowish pigmentation on the border. More rounded than pointed, reaches $1 \mathrm{~mm}$.

Eyes: Cerebral eyes numerous and arranged in a horseshoe shaped group (Figure 6B). Tentacular eyespots arranged in a line at the border (Figure 6A) and a group of eyespots at each tentacular tip (about 20). Frontally, in between psedotentacles, there are also clusters of eyespots, it is not clear if as an extension of the border eyespots groups or distinctive cluster 

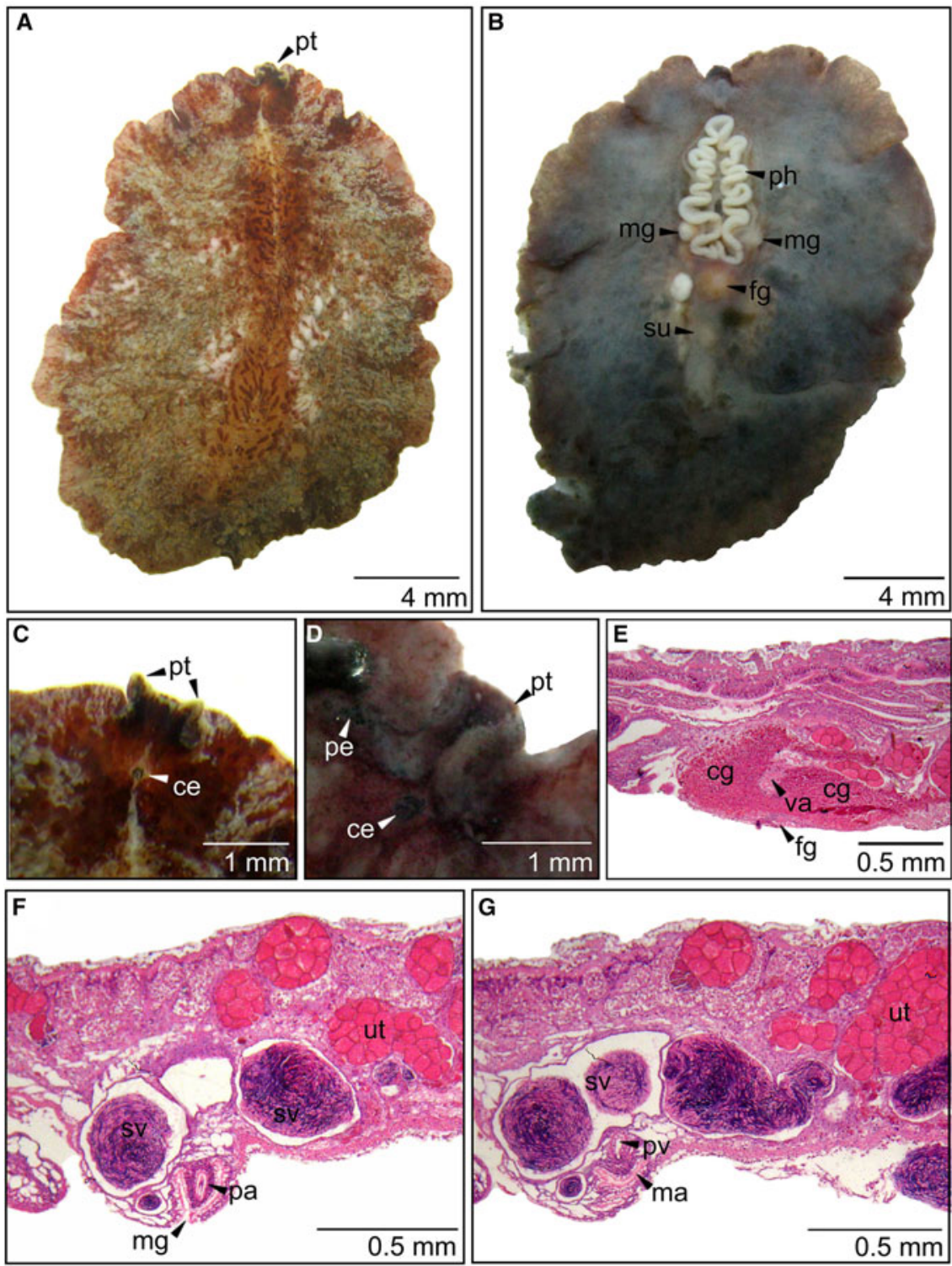

Fig. 5. Thysanozoon alagoensis sp. nov. (A) in vivo; (B) ventral view; (C) detail of the anterior margin, showing pseudotentacles; (D) detail of cerebral and tentacular eyespots; (E) sagittal section of female reproductive structures; (F) and (G) sagittal sections of male reproductive structures. ce, cerebral eyespots; $\mathrm{cg}$, cement glands; fg, female gonopore; ma, male atrium; mg, male gonopore; pa, penis papilla; pe, pseudotentacular eyespots; ph, pharynx; pt, pseudotentacles; pv, prostatic vesicle; su, sucker; sv, seminal vesicle; ut, uteri; va, vagina.

(Figure 6A). Ventral eyespots groups (Figure 6C) with about 25 eyespots.

Digestive system: Pharynx ruffled with seven simple folds (Figure $5 \mathrm{~B}$ ). Reaches $6 \mathrm{~mm}$. Mouth opens at $6 \mathrm{~mm}$ from the anterior margin.

Epidermis and body wall: Thin epidermis (Figure $5 \mathrm{D}$ ) and body wall $(0.04 \mathrm{~mm})$, even thinner ventrally (0.01). Sucker with $0.7 \mathrm{~mm}$ diameter is $2 \mathrm{~mm}$ behind the female pore.

Gonopores: Two male and one female gonopores present, $1.5 \mathrm{~mm}$ apart (Figure $5 \mathrm{~B}$ ). Male pores at $7 \mathrm{~mm}$ from the anterior margin, both measure $0.5 \mathrm{~mm}$ and the female pore $1 \mathrm{~mm}$

Male reproductive system: Seminal vesicle elongated and huge (Figure $5 \mathrm{E}$ ). Its extension reaches the front of the penial papillae and the seminal duct comes in a curve to join the penis. Penis papillae (Figure 5D) $0.18 \mathrm{~mm}$. Prostatic vesicle small $(0.09 \mathrm{~mm})$ and comma shaped (Figure ${ }_{5} \mathrm{E}$ ). Its duct joins the ejaculatory duct and enters the penis papillae
(Figure 6D). Seminal vesicle elongated and spermiducal vesicles greatly developed and reaching the region right above the male gonopore (Figure $5 \mathrm{E}$ ), maybe dislodging the seminal vesicle. Male atrium simple and $0.2 \mathrm{~mm}$ deep (Figure ${ }_{5} \mathrm{E}$ ).

Female reproductive system: Uteri well developed and full of eggs ( $0.089 \mathrm{~mm}$ diameter). Cement glands also well developed (Figure ${ }_{5} \mathrm{C}$ ).

\section{TAXONOMIC REMARKS}

Our specimen has a simple male atrium, different from the folded atrium found in Thysanozoon brocchii. Also the T. alagoensis has a different colouration pattern, and the dorsal papillae of this species are slender and Thysanozoon brocchii have rounder ones (Table 2). Other similar species such as Thysanozoon californicum (Hyman, 1953a) also has slender papillae and elongated pharynx with seven simple folds, but the colouration pattern differs from the Brazilian species 


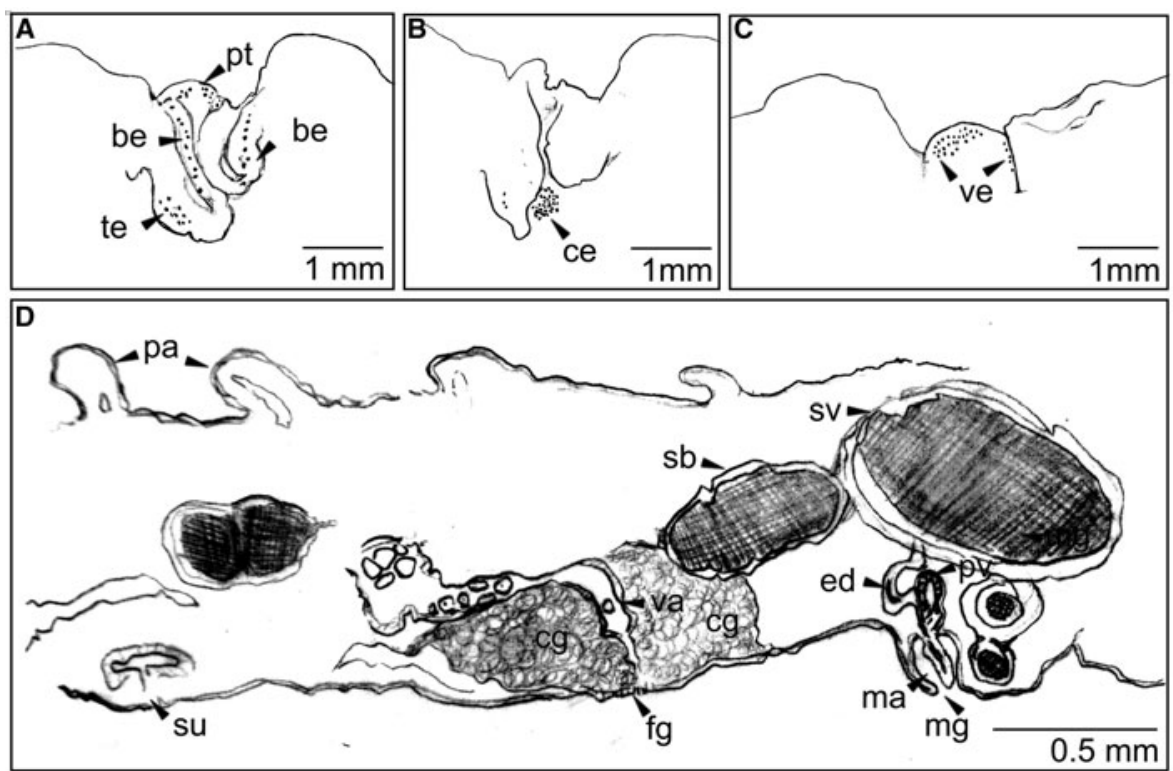

Fig. 6. Thysanozoon alagoensis sp. nov. (A) detail of pseudotentacular eyespots; (B) cerebral eyespots; (C) ventral eyespots; (D) tentative reconstruction of serial sections. be, pseudotentacle border eyespots; ce, cerebral eyespots; cg, cement glands; ed, ejaculatory duct; fg, female gonopore; ma, male atrium; mg, male gonopore; pa, papilla; pt, eyespots between pseudotentacles; pv, prostatic vesicle; sb, spermiducal bulbs; su, sucker; sv, seminal vesicle; te, pseudotentacles tips eyespots; va, vagina; ve, ventral eyespots.

(Table 2). The most similar species found in the literature is Thysanozoon mirtae, recently described from Argentina (Bulnes et al., 2011). However, there are marked differences between them, T. mirtae has a smaller pharynx $(5.5 \mathrm{~mm})$ and with fewer folds. This is especially distinctive as the specimen from Argentina is much larger, almost double the size of ours, and it would be expected that a larger specimen would have a larger pharynx. Also, the pseudotentacles of the Argentinian species are colourless and the ones in T. alagoensis are dark with yellowish tips. The Argentinian species also present rounded black spots in the dorsal surface that are absent in our specimen (Bulnes et al., 2011). Both T. alagoensis and T. mirtae have slender, elongated papillae, which are also found in Thysanozoon skottsbergi (Bock, 1913) and T. distinctum (Stummer-Traunfels, 1895), but the former has darker pigmentation on the papillae and the latter has a golden yellow margin which is markedly different from the reddish brown margin of T. alagoensis sp. nov. and T. mirtae. Both also have apparent spermiducal vesicles, but in $T$. alagoensis sp. nov. they are greatly developed. Yet another difference between these two South American species is the parenchymatic musculature, developed in T. alagoensis sp. nov. and not in T. mirtae. Other valid species of the genus are compared in Table 2. It is repeatedly stated in the literature that the female system is very uniform throughout the genus, therefore it was not included in the comparative table.

Suborder ACOTYLEA Lang, 1884

Family CRYPTOCELIDAE Laidlaw, 1902

Genus Phaenocelis von Stummer-Traunfels, 1933

Phaenocelis medvedica Marcus, 1952

(Figure 7)

\section{EXAMINED MATERIAL}

One specimen $(19 \times 5 \mathrm{~mm})$ as sagittal sections of reproductive structures (MNRJ-PLAT 97, 9 slides). Collected 6 January 2008 at Ponta Verde coral reef, Maceió, Alagoas, Brazil.

\section{GEOGRAPHIC DISTRIBUTION}

This species was described from São Paulo State, Brazil (Marcus, 1952), and is also known from the Caribbean coast of Colombia (Quiroga et al., 2004b). Here it is reported for the first time from north-eastern Brazil.

\section{DIAGNOSIS}

Rosaceous colour with brown pigment spots in two rows longitudinal to the body, parallel to the body axis (Figure $7 \mathrm{~A}$ ). Marginal eyespots small and present all over the body margin, disposed in a line (Figure $7 \mathrm{D}$ ). Cerebral eyespots scarce and disposed right in front of the brain; tentacular eyespots scarce in two small groups (Figure 7 C, D). Pharynx 1/3 of the body size and centrally disposed. Muscular layers disposed in the following order: longitudinal, circular, diagonal and longitudinal (Figure $7 \mathrm{~B}$ ).

\section{REMARKS}

Our specimen was immature and wounded at the level of reproductive structures, therefore on sagittal section it is possible only to identify the Lang's vesicle (Figure 6C, D).

Family STYLOCHOPLANIDAE Faubel, 1983 Genus Armatoplana Faubel, 1983

Armatoplana leptalea (Marcus, 1947)

(Figure 8)

\section{EXAMINED MATERIAL}

Three specimens $(16 \times 5 \mathrm{~mm}, 10 \times 3 \mathrm{~mm}$ and $10 \times 3 \mathrm{~mm})$, one as sagittal sections of reproductive structures (MNRJ-PLAT 98). Collected 10 January 2008 at Riacho Doce coral reef, Maceió, Alagoas, Brazil. One specimen $(11 \times$ $4 \mathrm{~mm}$ ) (MNRJ-PLAT 99, 5 slides). Collected 11 January 2008 at Saco da Pedra sandstone reef, Marechal Deodoro, Alagoas, Brazil. 
Table 2. Thysanozoon species characteristics comparison.

\begin{tabular}{|c|c|c|c|c|c|}
\hline Thysanozoon species & Colour pattern & Papillae & Pharynx & Male system & Distribution \\
\hline T. brocchii (Risso, 1818) & $\begin{array}{l}\text { Dark brown to yellowish } \\
\text { brown, cream cross } \\
\text { sometimes present at the } \\
\text { dorsal surface }\end{array}$ & $\begin{array}{l}\text { Slightly slender } \\
\text { to rounded }\end{array}$ & $\begin{array}{l}\text { Five simple } \\
\text { folds }\end{array}$ & $\begin{array}{l}\text { Seminal vesicle elongated } \\
\text { and located diagonally to } \\
\text { the body. Folded male } \\
\text { atrium. Spermiducal } \\
\text { vesicles absent }\end{array}$ & $\begin{array}{l}\text { Naples, Italy, } \\
\text { Mediterranean Sea, UK, } \\
\text { south and west of Africa, } \\
\text { Florida, Caribbean coast } \\
\text { of Colombia, Brazil, } \\
\text { Japan, New Zealand and } \\
\text { Canary Islands }\end{array}$ \\
\hline $\begin{array}{l}\text { T. californicum Hyman, } \\
\text { 1953a }\end{array}$ & $\begin{array}{l}\text { Reddish grey with mauve } \\
\text { margin, papillae yellowish } \\
\text { cream in the median line, } \\
\text { reddish grey in the rest of } \\
\text { the body and mauve in the } \\
\text { margins }\end{array}$ & $\begin{array}{l}\text { Slender and } \\
\text { elongated }\end{array}$ & $\begin{array}{l}\text { Seven simple } \\
\text { folds }\end{array}$ & Not sectioned & California \\
\hline $\begin{array}{l}\text { T. cruciatum } \\
\text { Schmmarda, } 1859 \text { a }\end{array}$ & $\begin{array}{l}\text { Light brown with reddish } \\
\text { touch, cream cross can be } \\
\text { present at the dorsal } \\
\text { surface. Greyish brown } \\
\text { papillae }\end{array}$ & Conic & $\begin{array}{l}\text { Three simple } \\
\text { folds }\end{array}$ & Not sectioned & New Zealand, Australia \\
\hline $\begin{array}{l}\text { T. discoideum } \\
\text { Schmmarda, 1859a }\end{array}$ & $\begin{array}{l}\text { Yellowish orange to blood } \\
\text { red, with dark reddish } \\
\text { brown median line. } \\
\text { Papillae brownish black to } \\
\text { black. Dark brown } \\
\text { tentacles }\end{array}$ & $\begin{array}{l}\text { Slender, almost } \\
\text { cylindrical }\end{array}$ & $\begin{array}{l}\text { Five simple } \\
\text { folds }\end{array}$ & Not sectioned & $\begin{array}{l}\text { Sri Lanka and Eastern } \\
\text { Africa }\end{array}$ \\
\hline $\begin{array}{l}\text { T. distinctum } \\
\text { Stummer-Traunfels, } \\
1895\end{array}$ & $\begin{array}{l}\text { Light yellow, whitish median } \\
\text { line and golden yellow } \\
\text { margin. Blackish and } \\
\text { whitish (more numerous) } \\
\text { papillae. Tentacles } \\
\text { blackish at base and yellow } \\
\text { at tips }\end{array}$ & $\begin{array}{l}\text { Slender, small } \\
\text { and } \\
\text { elongated }\end{array}$ & $\begin{array}{l}\text { Five simple } \\
\text { folds }\end{array}$ & $\begin{array}{l}\text { Oval seminal vesicle. } \\
\text { Spermiducal vesicles } \\
\text { absent }\end{array}$ & Edam and Java, Indonesia \\
\hline $\begin{array}{l}\text { T. flavotuberculatum } \\
\text { Hyman, 1939d }\end{array}$ & $\begin{array}{l}\text { Greyish with irregular small } \\
\text { black flecks. Scarce yellow } \\
\text { papillae }\end{array}$ & $\begin{array}{l}\text { Few oval } \\
\text { papillae }\end{array}$ & $?$ & Immature sectioned & Bermudas \\
\hline $\begin{array}{l}\text { T. hawaiiensis Hyman, } \\
1960\end{array}$ & $\begin{array}{l}\text { Light ochre with dull green } \\
\text { papillae }\end{array}$ & Cylindrical & $\begin{array}{l}\text { Five simple } \\
\text { folds }\end{array}$ & Not sectioned & Hawaii \\
\hline $\begin{array}{l}\text { T. langi } \\
\text { Stummer-Traunfels, } \\
1895\end{array}$ & $\begin{array}{l}\text { Bright dirty violet, with } \\
\text { darker violet mottling over } \\
\text { papillae }\end{array}$ & $\begin{array}{l}\text { Short and } \\
\text { rounded }\end{array}$ & $\begin{array}{l}\text { Five simple } \\
\text { folds }\end{array}$ & Not sectioned & Ambon, Indonesia \\
\hline $\begin{array}{l}\text { T. minutum } \\
\text { Stummer-Traunfels, } \\
1895\end{array}$ & $\begin{array}{l}\text { Yellowish grey with live red } \\
\text { median line, whitish } \\
\text { margin and tentacle } \\
\text { margin. Yellowish brown } \\
\text { papillae with reddish } \\
\text { brownish yellow and } \\
\text { bright round spots }\end{array}$ & $\begin{array}{l}\text { Short and } \\
\text { conic }\end{array}$ & $\begin{array}{l}\text { Five simple } \\
\text { folds }\end{array}$ & $\begin{array}{l}\text { Not sectioned. Vas deferens } \\
\text { well developed }\end{array}$ & Java, Indonesia \\
\hline $\begin{array}{l}\text { T. mirtae Bulnes et al. } \\
2011\end{array}$ & $\begin{array}{l}\text { Greenish yellow covered with } \\
\text { rounded black spots, } \\
\text { reddish brown papillae, } \\
\text { tentacles unpigmented }\end{array}$ & $\begin{array}{l}\text { Slender and } \\
\text { elongated }\end{array}$ & $\begin{array}{l}\text { Three simple } \\
\text { folds }\end{array}$ & $\begin{array}{l}\text { Vas deferens form } \\
\text { spermiducal vesicles. } \\
\text { Seminal vesicle with } \\
\text { well-developed muscular } \\
\text { wall and is arranged } \\
\text { dorsally to the male } \\
\text { prostatic vesicle and } \\
\text { stylet. Rounded prostatic } \\
\text { vesicle }\end{array}$ & Argentina \\
\hline $\begin{array}{l}\text { T. nigropapillosum } \\
\text { (Hyman, 1959a) }\end{array}$ & $\begin{array}{l}\text { Black with pale yellowish } \\
\text { margin. Black papillae } \\
\text { with white tips }\end{array}$ & $\begin{array}{l}\text { Short and } \\
\text { rounded }\end{array}$ & $\begin{array}{l}\text { Five simple } \\
\text { folds }\end{array}$ & Not sectioned & Ifaluk, Micronesia \\
\hline T. nigrum Girard, 1851 & $\begin{array}{l}\text { Black with grey patches and } \\
\text { fine specks of white. } \\
\text { Blackish papillae tinged } \\
\text { with greenish yellow }\end{array}$ & $\begin{array}{c}\text { Slender and } \\
\text { pointed }\end{array}$ & $?$ & $\begin{array}{l}\text { Oval prostatic vesicle. Wide, } \\
\text { long and coiled seminal } \\
\text { duct }\end{array}$ & Florida and Bermudas \\
\hline
\end{tabular}


Table 2. Continued

\begin{tabular}{|c|c|c|c|c|c|}
\hline Thysanozoon species & Colour pattern & Papillae & Pharynx & Male system & Distribution \\
\hline $\begin{array}{l}\text { T. raphaeli Bolaños et al., } \\
2007\end{array}$ & $\begin{array}{l}\text { Brown-blackish with } \\
\text { yellowish orange papillae. } \\
\text { Small white slash-like } \\
\text { marks, hardly visible, in } \\
\text { the margin. Black tentacles } \\
\text { sometimes outlined by } \\
\text { white marks }\end{array}$ & $\begin{array}{l}\text { Short and } \\
\text { rounded }\end{array}$ & $?$ & $\begin{array}{l}\text { Seminal vesicle elongated } \\
\text { and prostatic vesicle } \\
\text { rounded. Spermiducal } \\
\text { vesicles absent }\end{array}$ & Belize and Panama \\
\hline T. skottsbergi Bock, 1923c & $\begin{array}{l}\text { Yellowish with touch of } \\
\text { greenish grey, blackish } \\
\text { median line, lighter } \\
\text { papillae tipped with black. } \\
\text { Black tentacles }\end{array}$ & Slender & $\begin{array}{l}\text { Five simple } \\
\text { folds }\end{array}$ & Not sectioned & Juan Fernandez Islands \\
\hline T. alagoensis sp. nov. & $\begin{array}{l}\text { Greyish background colour } \\
\text { with reddish brown } \\
\text { papillae, reddish brown } \\
\text { margin and dark almost } \\
\text { black tentacles with a hint } \\
\text { of yellowish pigmentation } \\
\text { on the border. } \\
\text { Unpigmented line present } \\
\text { at the median line of the } \\
\text { body }\end{array}$ & $\begin{array}{r}\text { Slender and } \\
\text { elongated }\end{array}$ & $\begin{array}{l}\text { Pharynx ruffled } \\
\text { with seven } \\
\text { simple folds }\end{array}$ & $\begin{array}{l}\text { Seminal vesicle elongated } \\
\text { and huge, reaches the } \\
\text { front of penial papillae. } \\
\text { Ejaculatory duct comes } \\
\text { in a curve to join the } \\
\text { penis. Prostatic vesicle } \\
\text { small and comma } \\
\text { shaped. Male atrium } \\
\text { simple. Greatly } \\
\text { developed spermiducal } \\
\text { vesicles }\end{array}$ & Brazil \\
\hline
\end{tabular}

\section{GEOGRAPHIC DISTRIBUTION}

This species was described from São Paulo State, Brazil (Marcus, 1947), and also known from Bahia State and localities in the Caribbean, such as Antigua, Barbuda, Curaçao and Florida (Marcus \& Marcus, 1968). This is the first record of this species from Alagoas State.

\section{DIAGNOSIS}

Light brown colouration, mostly transparent (Figure 8A). Few eyespots posteriorly to tentacular region; tentacular eyespots in a densely disposed group. Cerebral and pre-cerebral eyespots disposed in long parallel groups. Pharynx in the anterior half of the body. Vagina wall ciliated and muscular (Figure 8C, D). Long penis with stylet, seminal vesicle highly muscularized (Figure 8B), Lang's vesicle present, granular vesicle elongated and directed backwards.

\section{REMARKS}

Our specimens slightly differ in the fact that the seminal vesicle is located under the granular vesicle and not behind it as illustrated in Marcus (1947: Figure 32), which can be due to the size of the specimens or fixation contraction. It is the first time that this species is illustrated with coloured photos of internal structures and live specimens.

\section{Family LATOCESTIDAE Laidlaw, 1902 \\ Genus Latocestus Plehn, 1896 \\ Latocestus brasiliensis Hyman, 1955}

(Figure 9)

\section{EXAMINED MATERIAL}

One specimen $(7 \times 1.5 \mathrm{~mm})$ as sagittal sections of reproductive structures (MNRJ-PLAT 101, 6 slides). Collected 7 February 2008 at Pajuçara coral reef, Maceió, Alagoas,
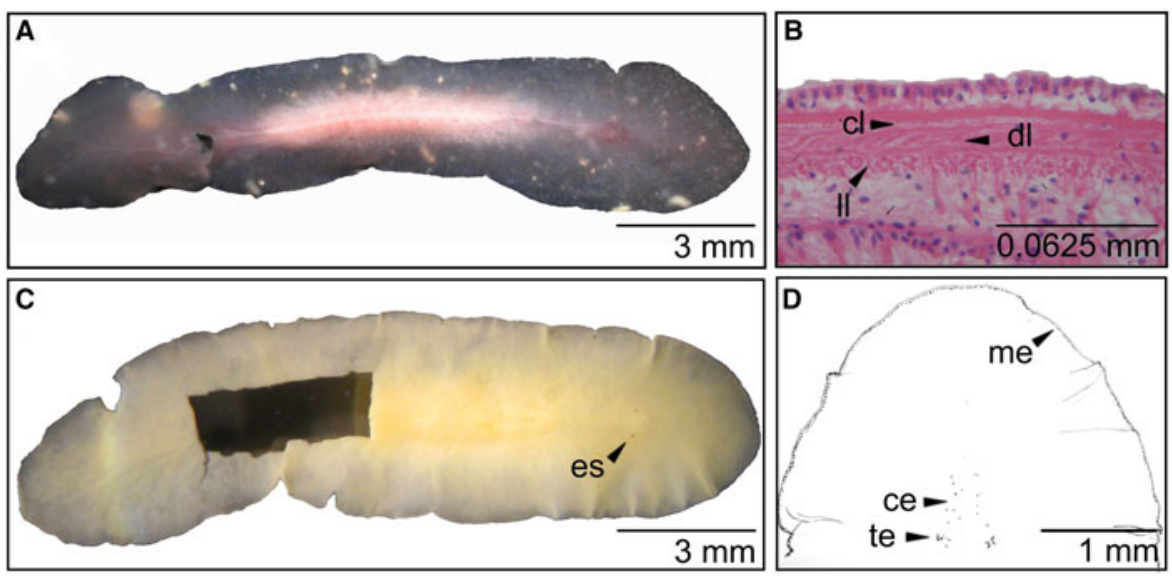

Fig. 7. Phaenocelis medvedica (A) in vivo; (B) sagittal section showing muscular layers; (C) fixed worm; (D) anterior region detail showing eyespots. ce, cerebral eyespots; cl, circular layer; dl, diagonal layer; es, eyespots; ll, longitudinal layer; lv, Lang's vesicle; me, marginal eyespots; te, tentacular eyespots. 

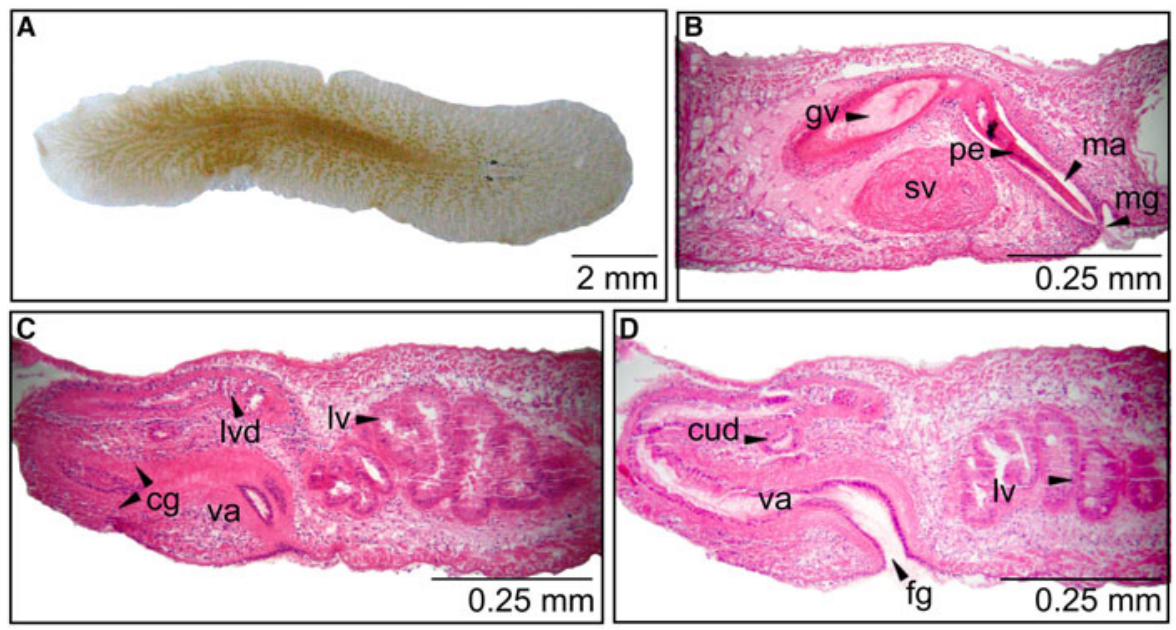

Fig. 8. Armatoplana leptalea (A) in vivo; (B) sagittal section of the male reproductive structures; (C) and (D) sagittal sections of the female reproductive structures. cud, common uterine duct; fg, female gonopore; gv, granular vesicle; lv, Lang's vesicle; lvd, Lang's vesicle duct; mg, male gonopore; pe, penis; sv, seminal vesicle; va, vagina.

Brazil. One specimen $(10 \times 2 \mathrm{~mm})$ as sagittal sections of reproductive structures (MNRJ-PLAT 107, 8 slides). Collected 28 January 2012 in algae at Ponta Verde coral reef, Maceió, Alagoas, Brazil.

\section{GEOGRAPHIC DISTRIBUTION}

In the original description Hyman (1955) did not mention the exact type locality and only writes the unspecific term 'off São Francisco'. However, in a later paper (Schmitt, 1926, p. 89), she states that the collector (Waldo L. Schmitt) travelled in southern Brazil in 1925, including Santa Catarina State. Off the coast of this region there is an island called São Francisco do Sul, and, most probably, Hyman referred to it in the original description. It is the first time it is reported after almost 60 years after the original description. This is the first record of this species in north-eastern Brazil.

\section{DIAGNOSIS}

Colour greyish beige (Figure 9A). Body form elongated, anterior part pointed, tentacles absent, marginal eyespots around

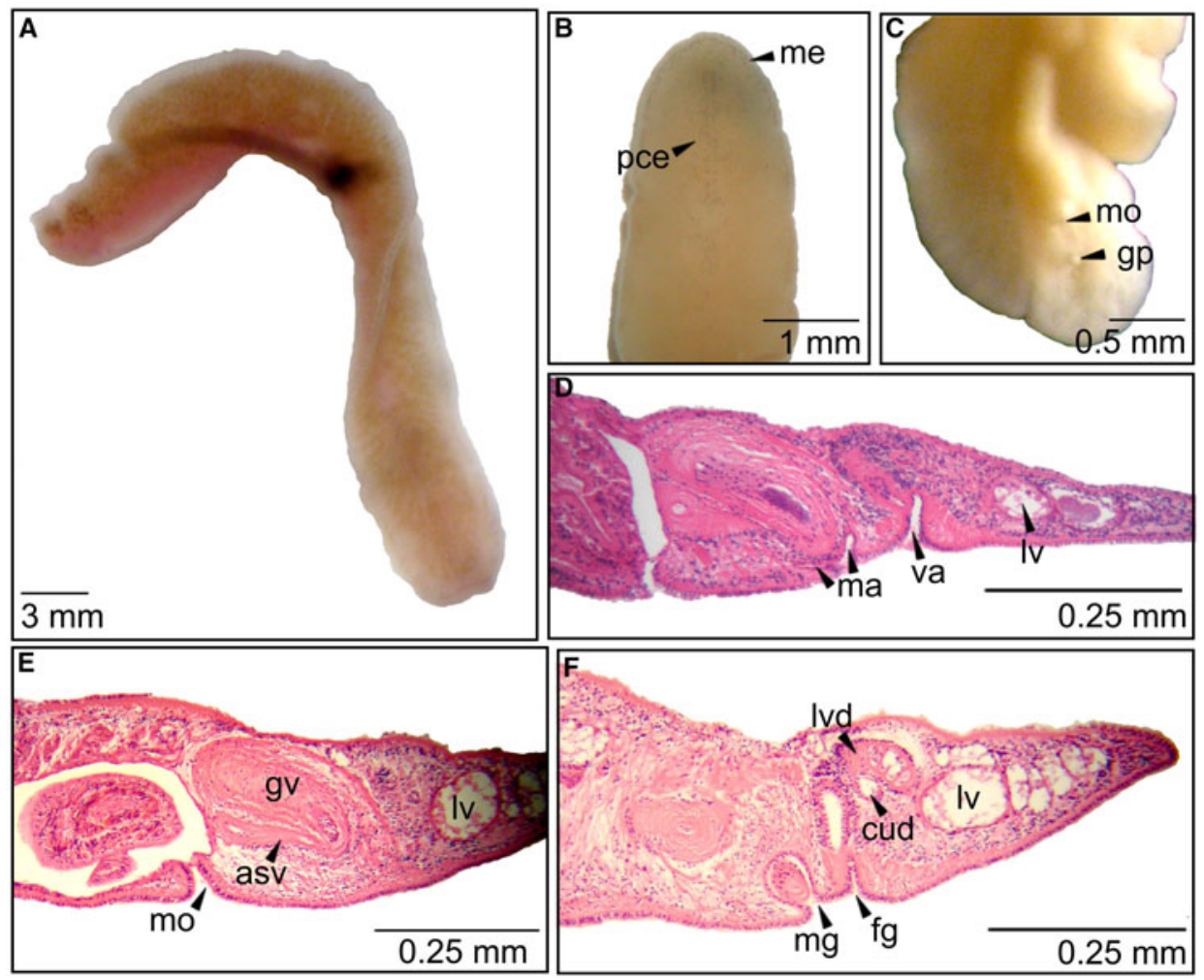

Fig. 9. Latocestus brasiliensis (A) in vivo; (B) detail of anterior region showing eyespots; (C) detail of the ventral posterior region showing mouth and gonopores; (D), (E) and (F) sagittal sections of reproductive structures. asv, accessory seminal vesicle; cud, common uterine duct; fg, female gonopore; gp, gonopores; gv, granular vesicle; lv, Lang's vesicle; lvd, Lang's vesicle duct; ma, male atrium; me, marginal eyespots; mg, male gonopore; mo, mouth; pce, precerebral eyespots; va, vagina. 
all body, precerebral eyespots in a fan-like arrangement (Figure 9B). Pharynx at the last third of the body. Mouth opens at posterior part of the body right in front of reproductive structures. Male aparat directed forward (Figure 9D). Male and female gonopores separated (Figure 9D, F). Female atrium and vagina ciliated, vagina turned backwards and connects to Lang's vesicle by a repeatedly expanded and constricted duct (Figure $9 \mathrm{~F}$ ). Granular vesicle and accessory seminal vesicle very muscularized (Figure ${ }_{9} \mathrm{E}$ ), elongated and directed forward.

\section{REMARKS}

Our specimens fit the original description and the redefinition of the genus by Faubel (1983). Other species of the genus, like Latocestos callizona Marcus, 1947 have different body form, eyespots arrangement and differences in reproductive structures both masculine and feminine. The species Latocestus atlanticus Plehn, 1896 also has a different eyespots arrangement. The species Prolatocestus ocellatus (Marcus, 1947) is mostly similar, but it has a common genital aperture and therefore is located in another genus. The material here studied fits the original description both internally and in eyespots arrangement.

Family DISCOCELIDAE Laidlaw, 1902 Genus Adenoplana Stummer-Traunfels, 1933 Adenoplana evelinae Marcus, 1950

(Figure 10)

\section{EXAMINED MATERIAL}

One specimen $(14 \times 10 \mathrm{~mm})$ as sagittal sections of reproductive structures (MNRJ-PLAT 102, 8 slides). Collected 18 January 2007 at Pajuçara, Maceió, Alagoas, Brazil. One specimen $(12 \times 6 \mathrm{~mm})$, collected 9 January 2008 at Brazil, Alagoas, Maceió, Recife do Francês (eaten by a Enchiridium evelinae). One specimen $(21 \times 12 \mathrm{~mm})$ (MNRJ-PLAT 103, 6 slides) collected 26 January 2012 at Saco da Pedra sandstone reef, Marechal Deodoro, Alagoas, Brazil, under rocks.

\section{GEOGRAPHIC DISTRIBUTION}

This species was described from São Paulo State, Brazil (Marcus, 1950) and is endemic from Brazil. This is the first record of this species from north-eastern Brazil and it is the second and northernmost record in the Brazilian coast.

\section{DIAGNOSIS}

Transparent body makes it possible to see gut contents (Figure 10A, B). Marginal eyespots (Figure 10C) surround all body, are arranged in a scattered broad line and become scarcer after the first third of the body. Tentacular eyespots located before the brain level (Figure 10C). Cerebral eyespots groups extend towards the margin and begin before the brain level (Figure $10 \mathrm{C}$ ). Male and female gonopores separated. Prostatoid organs present in the penis tissue (Figure $10 \mathrm{~F}$ ) and granular vesicle; male atrium spacious, vagina, common uterine duct and Lang's vesicle duct ciliated (Figure 10E).
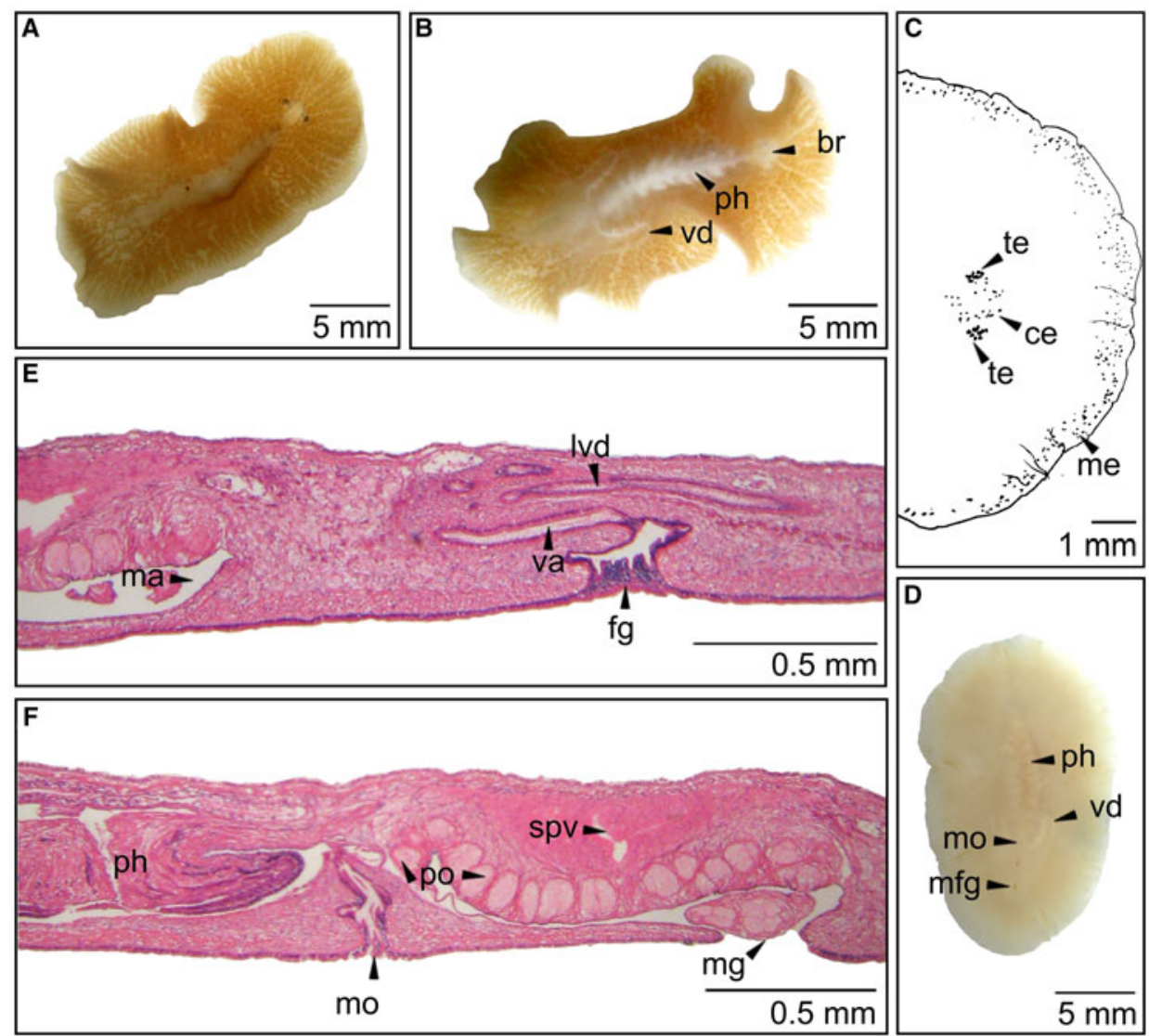

Fig. 10. Adenoplana evelinae (A) in vivo; (B) in vivo, ventral view; (C) detail of the anterior margin; (D) ventral view; (E) and (F) sagittal sections of reproductive structures. br, brain; ce, cerebral eyespots; fg, female gonopore; lvd, Lang's vesicle duct; me, marginal eyespots; mfg, male and female gonopores; mg, male gonopore; mo, mouth; ph, pharynx; po, prostatoids; spv, spermiductal vesicle; te, tentacular eyespots; va, vagina; vd, vas deferens. 
External vagina directed forward and female ducts directed backwards, towards the Lang's vesicle.

\section{REMARKS}

The other Tropical Western Atlantic Adenoplana species, A. obovata (Schmmarda, 1859a), does not have marginal eyespots surrounding the entire body margin (Hyman, 1955), as Adenoplana evelinae has. The South American species A. platae also has marginal eyespots all over the body, however it presents a rather elongated cerebral eyespots group and it begins at the brain level (Hyman, 1955).

\section{DISCUSSION}

The north-eastern Brazilian coast is mostly unexplored concerning polyclad biodiversity and most works about Brazilian Polycladida have been made on the south-eastern coast (Marcus, 1949, 1950, 1952). Until recently, only two species were reported from this region: Stylochoplana walsergia and Armatoplana leptalea, both from Bahia State, south of Alagoas State (Marcus \& Marcus, 1968). Bahia et al. (2012), based on material from Rio Grande do Norte State, reported six other species: Enchiridium evelinae, Phrikoceros mopsus, Pseudobiceros evelinae, Thysanozoon brocchii, Hoploplana divae. And recently, Queiroz et al. (2013) recorded Pericelis cata from Bahia State.

The present work adds six species to the north-eastern Brazilian coast: Pseudoceros bicolor, Pseudoceros rawlinsonae, Thysanozoon alagoensis sp. nov., Phaenocelis medvedica, Latocestus brasiliensis and Adenoplana evelinae. One of them is a new species and all 11 species are for the first time reported from Alagoas State. It is also the first time that Phaenocelis medvedica, Adenoplana evelinae, Latocestus brasiliensis and Armatoplana leptalea are illustrated by full colour photos of live specimens and histological sections. Our results emphasize that the Order Polycladida is not well known on the Brazilian coast and that the biodiversity of reef areas in Alagoas State is underestimated. More studies focused on polyclads are necessary to access their biodiversity throughout the Brazilian coast.

The different areas sampled in this study are subject to different levels of human impact (Correia \& Sovierzoski, 2010). The area with highest species richness, Saco da Pedra reef, has a good conservation status as it is within a Biological Reserve (Correia \& Sovierzoski, 2009). In contrast areas such as Piscina dos Amores coral reef, Pajuçara and Jatiúca reefs are more impacted reef areas, inside the urban perimeter of the city of Maceió and the city harbour. Apparently, polyclads can be used as bioindicators of environmental quality as they are more abundant and diverse in more pristine areas (personal observation). Since the 1980s the urban occupation in Maceió, and in the Brazilian coast in general, is growing without much planning and care, which threatens the biodiversity of reef areas. It is alarming that we are losing biodiversity before we even know its identity, and studies such as this one are relevant efforts to prevent or call attention to it.

\section{ACKNDWLEDGEMENTS}

We thank Arnaldo Campos Perez for histological slides and EcoScuba for the logistic support. We also thank Juan Lucas
Cervera, Juan Carlos García-Gomes, Luis Sanchez, Manuel Malaquias, Anderson Miranda, Elizabeth Torres, Vitor Cedro, Lilian Freitas, Alvaro Borba and Leandro Vieira for help in collections and sorting material.

\section{FINANCIAL SUPPORT}

We are grateful to CAPES (Coordenação de Aperfeiçoamento de Pessoal do Ensino Superior) and CNPq (Conselho Nacional de Desenvolvimento Científico e Tecnológico) for Juliana Bahia's scholarship during the collections. Both Juliana Bahia and Vinicius Padula have $\mathrm{PhD}$ grants from CNPq-Brazil and DAAD-Germany.

\section{Supplementary material and methods}

To view supplementary material for this article, please visit http://dx.doi.org/10.1017/Soo25315415000922.

\section{REFERENCES}

Bahia J. and Padula V. (2009) First record of Pseudoceros bicolor and Pericelis cata (Platyhelminthes: Polycladida) from Brazil. Marine Biodiversity Records 2, 1-5. doi: 10.1017/S1755267209000918.

Bahia J., Padula V. and Delgado M. (2012) Five new records and morphological data of polyclad species (Platyhelminthes: Turbellaria) from Rio Grande do Norte, Northeastern Brazil. Zootaxa 3170, 31-44.

Bahia J., Padula V., Passeri Lavrado H. and Quiroga S. (2014) Taxonomy of Cotylea (Platyhelminthes: Polycladida) from Cabo Frio, southeastern Brazil, with the description of a new species. Zootaxa 3873, 495-525.

Bispo A., Correia M.D. and Hajdu E. (2014) Two new shallow-water species of Haliclona from Northeastern Brazil (Demospongiae: Haplosclerida: Chalinidae). Journal of the Marine Biological Association of United Kingdom 94, 1-13. doi: 10.1017/Soo25315414000344.

Bock S. (1913) Studien über Polycladen. Zoologiska Bijdrag fran Uppsala 2, 31-344

Bock S. (1923c) Polycladen aus Juan Fernandez. Natural History of Juan Fernandez and Eastern Island, Uppsala 3 (Zoologie), 341-372.

Bolaños D.M., Quiroga S.Y. and Litvaitis M.K. (2007) Five new species of cotylean flatworms (Platyhelminthes: Polycladida) from the wider Caribbean. Zootaxa 1650, 1-23.

Brusa F., Damborenea C. and Quiroga S. (2009) First records of the Pseudocerotidae (Platyhelminthes: Polycladida: Cotylea) from Patagonia, Argentina. Zootaxa 2283, 51-59.

Bulnes V.N., Albano M.J., Obenat S.M. and Cazzaniga N.J. (2011) Three pseudocerotid (Platyhelminthes, Polycladida, Cotylea) species from the Argentinian coast. Zootaxa 2990, 30-44.

Cedro V.R., Hajdu E. and Correia M.D. (2011) Mycale alagoana new sp. and two new formal records of Porifera (Demospongiae, Poecilosclerida) from the shallow-water reefs of Alagoas (Brazil). Biota Neotropica 11, 161-171.

Cedro V.R., Hajdu E. and Correia M.D. (2013) Three new intertidal sponges (Porifera: Demospongiae) from Brazil's fringing urban reefs (Maceió, Alagoas, Brazil), and support for Rhabderemia's exclusion from Poecilosclerida. Journal of Natural History 47, 2151-2174.

Cedro V.R., Hajdu E., Sovierzoski H.H. and Correia M.D. (2007) Demospongiae (Porifera) of the shallow coral reefs of Maceió, Alagoas State, Brazil. In Custódio M.R., Lobo-Hajdu G., Hajdu E. \& 
Muricy G. (eds) Porifera research: biodiversity, innovation and sustainability. Rio de Janeiro: IMOS, pp. 233-237.

Correia M.D. (2011) Scleractinian corals (Cnidaria, Anthozoa) from reef ecosystems on the Alagoas coast, Brazil. Journal of the Marine Biological Association of the United Kingdom 91, 659-668. doi: $10.1017 /$ So025315410000858.

Correia M.D. and Sovierzoski H.H. (2009) Ecossistemas costeiros de Alagoas-Brasil. Rio de Janeiro: Technical Books Press.

Correia M.D. and Sovierzoski H.H. (2010) Macrobenthic diversity reaction to human impacts on Maceió coral reefs, Alagoas, Brazil. Proceedings of the 11th International Coral Reef Symposium. Fort Lauderlade, Florida (USA) 23, 1083-1087.

Faubel A. (1983) The Polycladida, Turbellaria Proposal and establishment of a new system Part I. The Acotylea. Mitteilungen hamburbischen zoologischen Museum und Institut 80, 17-121.

Faubel A. (1984) The Polycladida, Turbellaria Proposal and establishment of a new system Part II. The Cotylea. Mitteilungen Hamburbischen Zoologischen Museum und Institute 81, 189-259.

Grube A.E. (1840) Actinien, Echinodermen und Würmer des adriatischen und Mittelmeers, nach eigenen Sammlungenbeschrieben. Königsberg: Verlag von J. H. Bon, 92 pp.

Hyman L.H. (1939d) Acoel and polyclad Turbellaria from Bermuda and the Sargassum. Bulletin of the Bingman Oceanographic Collection 7 $1-26$.

Hyman L.H. (1953a) The polyclad flatworms of the Pacific coast of North America. Bulletin of the American Museum of Natural History 100 , 265-392.

Hyman L.H. (1955) Miscellaneous marine and terrestrial flatworms from South America. American Museum Novitates 1742, 1-33.

Hyman L.H. (1959a) A further study of Micronesian polyclad flatworms. Proceedings of the United States National Museum 108, 543-597.

Hyman L.H. (1960) Second report on Hawaiian Polyclads. Pacific Science 14, 308-309.

Laidlaw F.A. (1902) The marine Turbellaria, with an account of the anatomy of some of the species. The Fauna and Geography of the Maldive and Laccadive Archipelagoes 1, 282-312.

Lang A. (1884) Die Polycladen (Seeplanarien) des Golfes von Neapel und der angrenzenden Meeresabschnitte. Eine Monographie. Leipzig: Fauna Flora Golfes v. Neapel, Volume 11, ix +668 pp.

Lima M.L.F., Correia M.D., Sovierzoski H.H. and Manso C.L.C. (2011) New records of Ophiuroidea (Echinodermata) from shallow waters of Maceió, State of Alagoas, Brazil. Marine Biological Records 4, 110(e97). doi: 10.1017/S175526721100090X.

Lima M.L.F., Sovierzoski H.H. and Correia M.D. (2013) Temporal variation of Ophiuroids associated with the macroalga Amphiroa fragilissima on a Southwest Atlantic Coral Reef. Marine Ecology 34, 1-12. doi: $10.1111 /$ maec.12042.

Litvaitis M.K., Bolaños D.M. and Quiroga S.Y. (2010) When names are wrong and colours deceive: unraveling the Pseudoceros bicolor species complex (Turbellaria: Polycladida). Journal of Natural History 44, 829-845. doi: 10.1080/00222930903537074.

Marcus E. (1947) Turbelários marinhos do Brasil. Boletim da Faculdade de Filosofia, Ciências e Letras da Universidade de São Paulo, Zoologia 12, 99-206.

Marcus E. (1948) Turbellaria do Brasil. Boletim da Faculdade de Filosofia, Ciências e Letras da Universidade de São Paulo, Zoologia 13, 111-243.

Marcus E. (1949) Turbellaria brasileiros (7). Boletim da Faculdade de Filosofia, Ciências e Letras da Universidade de São Paulo, Zoologia $14,7-155$.
Marcus E. (1950) Turbellaria brasileiros (8). Boletim da Faculdade de Filosofia, Ciências e Letras da Universidade de São Paulo, Zoologia $15,69-190$

Marcus E. (1952) Turbellaria brasileiros (10). Boletim da Faculdade de Filosofia, Ciências e Letras da Universidade de São Paulo, Zoologia $17,5-186$

Marcus E. and Marcus E. (1968) Polycladida from Curaçao and faunistically related regions. Studies on the Fauna of Curaçao and other Caribbean Islands 101, 1-133.

Newman L. and Cannon L. (2003) Marine flatworms: the world of polyclads. Collingwood: CSIRO, $97 \mathrm{pp}$.

Padula V., Bahia J., Correia M.D. and Sovierzosky H. (2012) New records of opisthobranchs (Mollusca: Gastropoda) from Alagoas, Northeastern Brazil. Marine Biodiversity Records 5, 1-11. doi:

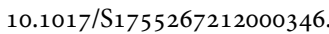

Prudhoe S. (1985) A monograph on Polyclad Turbellaria. London/Oxford: British Museum of Natural History and Oxford University Press.

Queiroz V., Sales L., Neves E.G. and Johnsson R. (2013) Pericelis cata Marcus \& Marcus, 1968 (Platyhelminthes: Polycladida): first record from northeast of Brazil. Check List 9, 628-630.

Quiroga S.Y., Bolaños D.M. and Litvaitis M.K. (2004a) Policládidos (Platyhelminthes: "Turbellaria") del Atlántico Tropical Ocidental. Biota Colombiana 5, 159-172.

Quiroga S.Y., Bolaños D.M. and Litvaitis M.K. (2004b) A checklist of polyclad flatworms (Platyhelminthes: Polycladida) from the Caribbean coast of Colombia, South America. Zootaxa 633, 1-12.

Rawlinson K.A. (2008) Biodiversity of coastal polyclad flatworm assemblages in the wider Caribbean. Marine Biology 153, 769-778. doi: 10.1007/s00227-007-0845-3.

Risso A. (1818) Sur quelques gasteropodes nouveaux, nudibranches et testibranches observes dans la mer de Nice. Journal de Physique Chimie et Histoire Naturelle 87, 368-376.

Santos C.G. and Correia M.D. (1994) Fitais do recife de coral da Ponta Verde, Maceió - Alagoas. Trabalhos Oceanográficos, UFPE 23, 79-89.

Santos C.G. and Correia M.D. (1995) Fauna associada ao fital Halimeda opuntia (Linnaeus) Lamouroux (Chlorophyta) do recife da Ponta Verde, Maceió - Alagoas. Revista Brasileira de Zoologia 12, 263-271.

Santos C.G. and Correia M.D. (2001) Composição quali-quantitativa do fital Halimeda opuntia (Linnaeus) (Chlorophyta) do recife da Pajuçara, Maceió, Alagoas. Revista Brasileira de Zoociências 3, 93-104.

Schmitt W.L. (1926) Explorations and field-work of the Smithsonian Institution in 1925. Study of the crustaceans of South America. Smithsonian Miscellaneous Collections 78, 89.

Schmmarda L.K. (1859a) Neue Turbellarien, Rotatorien und Anneliden beobachtet und gesammelt auf einer Reise um die Erde 1853 bis 1857. In Neue Wirbellose thiere I. Leipzig: Verlag von Wilhem Engelmann, pp. 1-66, 15pl.

Stummer-Traunfels R. (1895) Tropische Polycladen. I. Das Genus Thysanozoon Grube. Zeitschrift für wissenschaftliche Zoologie 60, $689-773$.

Stummer-Traunfels R. (1933) Polycladida (continued). In Bronn H.G. (ed.) Klassen und Ordnungen des Tier-Reichs IV. (Vermes). Leipzig: Akademic Verlagges, pp. 3485-3596.

Vera A., Moro L., Bacallado J.J. and Hernández F. (2008) Contribución al conocimiento de La biodiversidad de políclados (Platyhelminthes, Turbellaria) em las Islas Canarias. Revista de la Academia Canaria de Ciencias 20, 45-59.

Verrill A.E. (1900) Additions to the Turbellaria, Nemertina and Annelida of the Bermudas, with revisions of some New England genera and 
species. Transactions of the Connecticut Academy of Arts and Sciences 10, 595-672.

Verrill A.E. (1901) Additions to the fauna of the Bermudas from the Yale Expedition of 1901, with notes on other species. Transactions of the Connecticut Academy of Arts and Sciences 11, 15-62.

Vieira L.M., Gordon D.P. and Correia M.D. (2007) First record of a living Ditaxiporine Catenicellid in the Atlantic, with a description of Vasignyella ovicellata n. sp. (Bryozoa). Zootaxa 1582, $49-58$.

Vieira L.M., Migotto A.E. and Winston J.E. (2008) Synopsis and annotated checklist of recent marine Bryozoa from Brazil. Zootaxa 1810, $1-39$. and

Vieira L.M., Migotto A.E. and Winston J.E. (2010) Shallow-water species of Beania Johnston, 1840 (Bryozoa, Cheilostomata) from the tropical and subtropical Western Atlantic. Zootaxa 2550, 1-20.

\section{Correspondence should be addressed to:}

J. Bahia

SNSB-Zoologische Staatssammlung München, Münchhausenstrasse 21, 81247, München, Germany

email: ju.bahia@yahoo.com 